\title{
IMPLEMENTASI PENDEKATAN PROSES DALAM PEMBELAJARAN MENULIS CERITA PENDEK
}

\author{
Siti Halidjah \\ Pendidikan Guru Sekolah Dasar, FKIP, Untan, Pontianak \\ Email: sitihalidjah_pgsduntan@yahoo.co.id
}

\begin{abstract}
This study aims to gain a deep understanding of the implementation of the process approach in teaching writing short stories on students of PGSD FKIP Untan. This study used a qualitative approach. Sources of data in this research is learning events to write a short story using a process approach. Research procedures used in this study is the planning, implementation, data analysis, and report writing. Data collection technique used is the technique of direct observation and document scrutiny. Data collection tool used is a field record sheets and documentation with regard to the learning process and learning outcomes. This research data analysis begins with data collection, data reduction, data presentation, and conclusion / verification. Based on the results and discussion of this research can be concluded that the process approach can improve the skills of students to write short stories. This increase can be seen from both process and product. Learning to write by following the steps in the process approach can help lecturers provide variety and stimulation in a given assignments to write short stories. In the process of improvement can be seen from the learning process with the creative writing process approach in the activities of the students and the classroom situation in learning creative writing poetry, while in terms of products increase student skills to write short stories.
\end{abstract}

Keywords: process approach, teaching writing, short story

\section{PENDAHULUAN}

Penulis merupakan satu di antara empat keterampilan berbahasa yang harus dikuasai oleh mahasiswa. Menulis sebagai bagian dari keterampilan berbahasa merupakan bentuk komunikasi yang dapat dilakukan oleh mahasiswa untuk mengungkapkan ide atau gagasan, pikiran, dan perasaan dengan bahasa tulis sebagai medianya.

Pembelajaran menulis memberikan banyak manfaat, seperti pengembangan kreativitas, cara berpikir, kecerdasan, dan kepekaan emosi mahasiswa. Pembelajaran menulis juga diarahkan untuk membantu mereka menuangkan ide atau gagasan, pikiran, pengalaman, perasaan, dan cara mereka memandang kehidupan. Dengan banyaknya amanat yang akan diperoleh dalam pembelajaran menulis, selayaknya kegiatan menulis ini menjadi satu di antara kegiatan yang disukai mahasiswa. Akan tetapi, kenyataan menunjukkan pembelajaran menulis menjadi kegiatan yang cukup sulit bagi mahasiswa sehingga mereka kurang berminat terhadap pembelajaran menulis. Kesulitan tersebut akan semakin bertambah jika mereka dihadapkan pada pemelajaran menulis kreatif sastra. Padahal dalam pembelajaran menulis, mahasiswa diharapkan juga mampu menulis ide atau gagasan, pikiran, dan perasaannya dalam bentuk tulisan kreatif sastra.

Tujuan pembelajaran menulis kreatif sastra 
adalah agar mahasiawa mampu menulis kreatif, menyunting karangan sendiri atau karangan orang lain dengan memperhatikan penggunan ejaan, tanda baca, pilihan kata, struktur kalimat, dan kepaduan isi karangan. Menulis kreatif sastra meliputi menulis puisi, prosa fiksi, dan naskah drama. Menulis cerpen merupakan kegiatan mahasiswa menuangkan gagasan atau ide, pikiran, perasaan, dan kepekaan emosi yang berkembang dari gagasan kreatif.

Keterampilan menulis cerpen, juga seperti keterampilan menulis lainnya memerlukan proses dalam peaksanaannya. Keterampilan menulis itu tidak dapat diperoleh dengan serta merta. Keterampilan menulis yang dimiliki oleh sastrawan atau bukan sastrawan tidak datang begitu saja, sebuah tulisan yang baik harus mengandung isi, yang dikemukakan secara sistematis dan menarik. Meskipun sseorang memiliki gagasan atau ide tulisan yang baik dan menarik, tetapi kalau dia tidak mampu mengemukakan gagasan dan idenya itu secara teratur dan tahap demi tahap yang jelas dalam tulisannya, dia pasti gagal menyampaikan pendapatnya yang baik tadi pada pembacanya (Caraka, 1999:5).

Menulis cerpen dapat dipelajari dan perlu dilatihkan berkali-kali agar berhasil dalam menulis ceren dengan baik. Oleh karena itu, agar mahasiswa juga mampu menulis cerpen dengan baik, dosen harus memiliki kemampuan dan keterampilan membimbing mahasiswa dalm menulis cerpen. Mahasiswa tidak akan cukup hanya dibekali dengan teori, mahasiswa perlu diberikan arahan dan bimbingan agar dapat menghasilkan cerpen dengan baik tanpa harus kehilangan kreatifitasnya. Kondisi pembelajaran menulis cerpen yang demikian, mengharuskan dosen untuk mencari strategi yang tepat dan sesuai, agar kemampuan menulis cerpen dapat ditingkatkan. Semi (2002:134) berpendapat bahwa rendahnya kualitas pembelajaran menulis sastra disebabkan oleh berbagai faktor, seperti kurikulum, sarana belajar, dan pengajar (guru/dosen). Guru/ dosen sering tidak menggunakan pendekatan yang tepat. Satu di antara pendekatan yang dapat digunakan untuk membantu mahasiswa mengatasi kendala-kendala dalam menulis cerpen adalah pendekatan proses. pendekatan yang diterapkan mampu membimbing dan mengarahkan mahasiswa untuk mengatasi kendala-kendala yang dihadapinya dalam menulis cerpen.

Pendekatan proses adalah pendekatan yang menekankan pembelajaran menulis dari hasil (tulisan) ke proses menulis yang terlibat dalam menghasilkan tulisan. Pendekatan ini dipilih karena memiliki beberapa kelebihan. Dalam pelaksanaannya mahasiswa memiliki topik sendiri atau topik-topik yang diambil dari bidang studi lain. Dosen mengajar mahasiswa mengenai proses menulis dan bentuk-bentuk tulisan. Pembelajaran berfokus pada proses yang digunakan. Ketika menulis, mahasiswa merasa memiliki tulisan sendiri. Mahasiswa menulis dengan bekerja sama dan berbagi tulisan yang dihasilkan masing-masing dengan teman-teman satu kelompok/ kelas. Selain itu, mahasiswa menulis draft kasar (outline) untuk menuangkan gagasan dan kemudian merevisi dan menyunting draft ini sebelum membuat hasil akhir. Mahasiswa mengoreksi kesalahan sebanyak-banyaknya selain menyunting, tetapi tekanannya lebih pada isi daripada segi mekanik. Dosen mengajarkan cara menulis dan memberikan balikan selama pembelajar merevisi dan mengedit/menyunting. Mahasiswa mungkin menghabiskan waktu tidak hanya satu jam pelajaran untuk mengerjakan setiap tugas menulis sehingga mahaiswa dapat memanfaatkanya untuk memperbaiki tulisannya, dan evaluasi berfokus pada proses dan hasil.

Berdasarkan latar belakang masalah yang telah dipaparkan sebelumnya, penelitian ini bertujuan untuk mendapatkan pemahaman yang mendalam tentang implementasi pendekatan proses dalam pembelajaran menulis cerita pendek pada mahasiswa Program Studi PGSD FKIP Untan. Hasil penelitian ini diharapkan dapat dimanfaatkan sebagai satu di antara alternatif pendekatan dalam menulis dan juga merupakan sumbangan pemikiran bagi dosen untuk meningkatkan keberhasilan pembelajaran keterampilan menulis menggunakan pendekatan 
proses.

Pembelajaran menulis adalah upaya membantu dan mendorong siswa mengekspresikan bahasa dalam bentuk tulis, atau komponen yang disiapkan pendidik untuk menghasilkan perubahan tingkah laku dalam pembelajaran menulis. Hal ini sejalan dengan pendapat Tarigan (1986:9) berpendapat bahwa pembelajaran menulis adalah (1) membantu siswa memahami cara mengekspresikan bahasa dalam bentuk tulis; (2) mendorong siswa mengekspresikan diri secara bebas dalam bahasa tulis; (3) membantu siswa menggunakan bentuk bahasa yang tepat dan serasi dalam ekspresi tulis.

Berhasil atau tidaknya pengajaran menulis, salah satunya disebabkan oleh cara yang ditempuh guru dalam mengajarkan menulis. Menurut Nurchasanah dan Widodo (1993:70 72), ada empat hal yang perlu diperhatikan dalam mengajarkan kemampuan menulis, yaitu prinsip, pembimbingan, sifat pengajaran, dan media.

Pembelajaran menulis merupakan salah satu bagian dari bahasa dan sastra Indonesia, untuk dapat menyusun suatu karangan yang baik diperlukan beberapa syarat, antara lain kemampuan berbahasa, pengetahuan struktur bahasa, kemampuan memilih, dan menentukan tema karangan dan harus banyak membaca dan berlatih. Tujuan pembelajaran menulis di sekolah menurut Natia (1994:33-64) adalah (1) terampil mencari dan menemukan gagasan, idea atau topik yang cukup terbatas dan menarik untuk dikembangkan menjadi cerita, (2) terampil mengembangkan gagasan, ide atau topik dan menyusunnya menjadi karangan yang dapat dipertanggungjawabkan, (3) terampil mengungkapkan gagasan, ide atau topik yang dikembangkan dan disusun sebagai bahasa yang efektif, (4) melatih keterampilan siswa menguraikan pengalaman yang diterima di sekolah maupun di masyarakat dalam bahasa tulis, (5) mendorong siswa berpikir sistematis karena pekerjaan mengarang berarti melibatkan siswa berpikir teratur, dan (6) mendorong dan melatih siswa agar berbakat mengarang.

Menurut Nurchasanah dan Widodo
(1993:62-66), tujuan pembelajaran menulis dapat ditentukan berdasarkan aspek yang diinginkan dicapai oleh siswa. Tujuan tersebut antara lain (1) tujuan yang bersifat teoretis dan praktis, biasanya diwujudkan dalam pengajaran menulis secara serentak, maksudnya dalam pertemuan pengajaran tertentu siswa diharapkan dapat mencapai tujuan yang bersifat teoretis sekaligus dapat mencapai tujuan yang bersifat praktis, (2) tujuan berdasarkan wujud tulisan/ karangan, maksudnya tujuan pengajaran menulis dapat didasarkan atas wujud tulisan yang diharapkan dikuasai oleh siswa, (3) tujuan berdasarkan tingkat kognisi yang dicapai, yaitu tujuan yang bersifat ingatan, pemahaman, penerapan, analisis, sintesia, dan evaluasi, (4) tujuan langsung dan tidak langsung, di mana tujuan langsungnya adalah agar siswa dapat menulis secara langsung tanpa melalui tahapan kegiatan prasyarat, sedangkan tujuan tidak langsungnya adalah siswa dapat menulis dengan melalui tahapan-tahapan kegiatan prasyarat, dan (5) tujuan yang bersifat diskrit dan pragmatik, yakni pengajaran menulis yang bersifat diskrit bertujuan ingin melihat aspekaspek kemampuan menulis secara terpisahpisah, sedangkan pengajaran menulis yang bersifat pragmatik bertujuan ingin melihat kemampuan menulis secara utuh.

Cerita pendek atau cerpen merupakan sebuah karya sastra berbentuk prosa dan mempunyai komposisi cerita, tokoh, latar, yang lebih sempit dari pada novel. Cerita yang disajikan dalam cerpen terbatas hanya memiliki satu kisah. Cerpen (Short Story) merupakan salah satu bentuk karya sastra yang sekaligus disebut fiksi. Menurut Sumardjo (2007:84), cerpen adalah seni keterampilan menyajikan cerita. Oleh karena itu, seseorang penulis harus memiliki ketangkasan menulis dan menyusun cerita yang menarik. Sayuti (2009:10), menyatakan cerpen menunjukkan kualitas yang bersifat compression 'pemadatan', concentration 'pemusatan', dan intensity 'pendalaman', yang semuanya berkaitan dengan panjang cerita dan kualitas struktural yang diisyaratkan oleh panjang cerita itu. Berdasarkan pendapat para ahli di atas dapat 
disimpulkan bahwa cerpen adalah cerita pendek yang memiliki komposisi lebih sedikit dibanding novel dari segi kependekan cerita, memusatkan pada satu tokoh, satu situasi dan habis sekali baca.

Cerita pendek merupakan bentuk karya sastra fiksi yang menarik untuk dibaca yang disebabkan cerita yang disajikan pendek, tokoh terbatas, dan terdiri satu situasi. Cerita pendek juga tersusun atas unsur-unsur pembangun cerita yang saling berkaitan erat antara satu dengan yang lainnya. Keterkaitan antara unsur-unsur pembanguncerita tersebut membentuk totalitas yang bersifat abstrak. Koherensi dan keterpaduan semua unsur cerita yang membentuk sebuah totalitas amatmenentukan keindahan dan keberhasilan cerpen sebagai suatu bentuk ciptaan sastra. Unsur-unsur dalam cerita pendek terdiri atas: alur atau plot, penokohan,latar (setting), sudut pandang (poin of view), gaya bahasa, tema, dan amanat.

Menulis cerita pendek pada hakikatnya merujuk pada kegiatan mengarang, dan mengarang termasuk tulisan kreatif yang penulisannya dipengaruhi oleh hasil rekaan atau imajinasi pengarang. Menulis cerpen merupakan cara menulis yang paling selektif dan ekonomis. Cerita dalam cerpen sangat kompak, tidak ada bagiannya yang hanya berfungsi sebagai embelembel. Tiap bagiannya, tiap kalimatnya, tiap katanya, tiap tanda bacanya, tidak ada bagian yang sia-sia, semuanya memberi saran yang penting untuk menggerakkan jalan cerita, atau mengungkapkan watak tokoh, atau melukiskan suasana. Sayuti (2009:8) mengatakan bahwa tulisan fiksi dibuat secara khayali atau tidak sungguh-sungguh terjadi dalam dunia nyata sehingga sering juga disebut sebagai cerita rekaan, atau cerita yang direka-reka oleh pengarangnya. Menulis cerita pendek memiliki daya imajinasi yang tinggi, semakin tinggi imajinasi yang dimiliki oleh pengarang semakin bagus cerita yang dihasilkan. Pengembangan keterampilan menulis cerita pendek melalui beberapa tahap, yaitu mengembangkan unsurunsur cerita pendek untuk dituangkan dalam bentuk tulisan.

Kisi-kisi penilaian menulis cerita pendek berdasarkan penilaian hasil karangan (Nurgiyantoro, 2009:306) dengan pengembangan secukupnya. Kisi-kisi penilaian dipilih karena sudah memenuhi kelengkapan baik dari segi penilaian isi maupun mekanik. Bobot skor pada tiap aspek didasarkan pada tingkat pentingnya masing-masing aspek dalam karangan. Untuk lebih jelasnya dapat dilihat pada tabel berikut ini.

Tabel 1. Kisi-kisi Penilaian Menulis Cerpen

\begin{tabular}{|c|c|c|}
\hline $\begin{array}{c}\text { Skor } \\
\text { Maksimal }\end{array}$ & Aspek & Kriteria \\
\hline \multirow[t]{4}{*}{20} & Isi & Kesesuaian Cerita dengan Tema \\
\hline & & Kreativitas dalam Mengembangkan Cerita \\
\hline & & Ketuntasan Cerita \\
\hline & & Kesesuaian Cerita dengan Sumber Cerita \\
\hline \multirow[t]{3}{*}{15} & $\begin{array}{l}\text { Organisasi dan } \\
\text { Penyajian }\end{array}$ & $\begin{array}{l}\text { Penyajian Unsur-Unsur berupa Tokoh, Alur, dan Latar } \\
\text { Cerita }\end{array}$ \\
\hline & & Kepaduan Unsur-unsur Cerita \\
\hline & & Kelogisan Urutan Cerita \\
\hline \multirow[t]{3}{*}{15} & Bahasa & Pilihan Kata atau Diksi \\
\hline & & Penyusunan Kalimat \\
\hline & & Penggunaan Majas \\
\hline
\end{tabular}


Pendekatan proses merupakan pendekatan pembelajaran yang menekankan pada proses belajar, aktivitas dan kreatifitas peserta didik dalam memperoleh pengetahuan, keterampilan, nilai dan sikap, serta menerapkannya dalam kehidupan sehari-hari. Dalam pengertain tersebut, meliputi keterlibatan fisik, mental dan social peserta didik dalam proses pembelajaran, untuk mencapai suatu tujuan. Pendekatan proses bertolak dari suatu pandangan bahwa setiap peserta didik memiliki potensi yang berbeda, dan dalam situasi yang normal, mereka dapat mengembangkan potensinya secara optimal. Oleh katena itu, tugas guru sebagai pendidik adalah memberikan kemudahan kepada peserta didik dengan menciptakan lingkungan yang kondusif agar semua perta didik dapt berkembang decara optimal.

Pendekatan proses merupakan pendekatan pengajaran yang memberikan kesempatan kepada siswa untuk menghayati proses penemuan atau penyusunan suatu konsep sebagai suatu keterampilan proses. Pendekatan proses adalah pendekatan yang berorientasi pada proses bukan hasil. Pada pendekatan ini peserta didik diharapkan benar-benar menguasai proses. Pendekatan ini penting untuk melatih daya pikir atau mengembangkan kemampuan berpikir dan melatih psikomotor peserta didik. Dalam pendekatan proses peserta didik juga harus dapat mengilustrasikan atau memodelkan dan bahkan melakukan percobaan. Evaluasi pembelajaran yang dinilai adalah proses yang mencakup kebenaran cara kerja, ketelitian, keakuratan, keuletan dalam bekerja dan sebagainya.

Pendekatan proses adalah pendekatan belajar mengajar yang mengarah kepada pengembangan kemampuan mental, fisik dan sosial yang mendasar untuk menggerakkan kemampuan yang lebih tinggi dalam diri pribadi murid. Keterampilan berarti kemampuan menggunakan pikiran atau nalar, sedangan perbuatan yang efisien dan efektif untuk mencapai suatu hasil tertentu termasuk kreatifitas.

Pendekatan proses merupakan pendekatan yang terpusat pada siswa. Siswa diberikan kesempatan seluasnya untuk mengembangkan pengetahuan, sikap, pengalamam, dan keterampilan dalam pembelajaran. Pendekatan proses tidak dilaksanakan secara serempak melainkan secara bertahap yang meliputi (a) tahap persiapan, (b) tahap pelaksanaan, dan (c) tahap tindak lanjut. Pendekatan proses akan efektif jika sesuai dengan kesiapan intelektual. Oleh karena itu, pendekatan proses harus tersusun menuruturutanyang logis sesuai dengan tingkat kemampuan dan pengalaman siswa, misalnya sebelum melaksanakan penelitian, siswa terlebih dahulu harus mengobservasi atau mengamati dan membuat hipotesis. Alasannya agar siswa dapat menciptakan kembali konsep-konsep yang ada dalam pikiran dan mampu mengorganisas-ikannya. Dengan demikian, keberhasilan anak dalam belajar bahasa Indonesia dalam menulis karangan menggunakan pendekatan proses adalah suatu perubahan tingkah laku dari seorang anak yang belum paham terhadap bahasa Indonesia yang sedang dipelajari sehingga menjadi paham dan mengerti permasalahannya.

Pendekatan proses merupakan alternatif yang dapat meningkatkan hasil belajar menulis. Secara umum pembelajaran menulis berdasarkan pendekatan proses mempunyai tahapan (1) strategi pramenulis, (2) strategi pengedrafan, (3) strategi perbaikan isi, dan (4) strategi penyuntingan. Kegiatan menulis dengan pendekatan proses dilakukan secara bertahap dari awal penggalian ide sampai tahap publikasi. Tompkins (2010:52-60) membagi tahapan dalam menulis menjadi lima tahap yaitu prapenulisan, membuat draf, revisi, menyunting dan publikasi. Tompkins juga menekankan bahwa tahap-tahap menulis ini tidak merupakan kegiatan yang linear. Proses menulis bersifat nonlinier, artinya merupakan putaran berulang. Misalnya, setelah selesai menyunting tulisannya, penulis mungkin ingin meninjau kembali kesesuaiannya dengan kerangka tulisan atau draf awalnya. Kegiatankegiatan yang dilakukan pada setiap tahap itu dapat dirinci lagi. Dengan demikian, tergambar secara menyeluruh proses menulis, mulai awal sampai akhir menulis. 


\section{METODE}

Penelitian ini menggunakan pendekatan kualitatif. Bogdan dan Taylor dalam Aminuddin (1990:14) menyatakan bahwa penelitian kualitatif adalah prosedur penelitian yang menghasilkan data deskriptif berupa kata-kata tertulis atau lisan tentang orang-orang dan perilaku yang dapat diamati.

Pendekatan ini dipilih sesuai dengan judul penelitian yang akan meneliti masalah pembelajaran di kelas. Hal ini sesuai dengan ciri-ciri penelitian kualitatif, yaitu (a) data dalam penelitian ini dikumpulkan secara langsung dari lingkungan nyata, (b) menusia sebagai instrumen, (c) bersifat deskriptif, dan (d) lebih mengutamakan proses dari pada hasil.

Sumber data dalam penelitian ini adalah peristiwa pembelajaran menulis cerita pendek menggunakan pendekatan proses. Datadiperoleh dari subjek yang diteliti, yaitu mahasiswa PGSD FKIP Untan semester III. Pemilihan PGSD FKIP Untan sebagai tempat penelitian dengan pertimbangan dosen peneliti merupakan dosen tetap di program studi tersebut. Pemilihan dan pertimbangan penelitian dilaksanakan pada mahasiswa semester III dilihat dari mata kuliah yang muncul di semester gasal. Mata kuliah yang berkenaan adalah Pembelajaran Bahasa dan Sastra Iindonesia Kelas Tinggi. Menulis cerita pendek bagian dari pokok bahasan mengarang fiksi merupakan kompetensi pembelajaran yang wajib dikuasai mahasiswa calon guru sekolah dasar. Prosedur penelitan yang digunakan dalam penelitian ini mengacu adalah perencanaan, pelaksanaan, analisis data, dan penulisan laporan.

Teknik pengumpul data yang digunakan dalam penelitian ini adalah teknik observasi langsung dan pencermatan dokumen. Alat pengumpul data yang digunakan adalah lembar catatan lapangan dan dokumentasi yang berkenaan dengan proses pembelajaran dan hasil belajar. Analisis data penelitian ini dilakukan dengan mengikuti alur analisis data yang dikembangkan oleh Miles dan Hubberman (1992:15-20). Kegiatan analisis dimulai dengan pengumpulan data, reduksi data, penyajian data, dan penyimpulan/ verifikasi.

\section{HASIL PENELITIAN DAN PEMBAHASAN} Hasil Penelitian

Penelitian tentang pembelajaran menulis cerita pendek menggunakan pendekatan proses dilakukan dengan tiga tahapan, yaitu perencanaan, pelaksanaan, dan analisis data. Tahap perencanaan, penulis mengidentifikasi permasalahan yang terjadi dalam pembelajaran menulis cerpen dan mencari solusi yang tepat untuk digunakan dalam meningkatkan keterampilan mahasiswa menulis cerpen.

Tahap Perencanaan. Langkah pertama yang dilakukan setelah melakukan identifikasi masalah adalah dengan menugaskan mahasiswa menulis cerpen dengan tema yang telah disepakati. Cerpen yang dihasilkan dianalisis dari sisi unsur pembangun sebuah cerpen. Setelah diketahui kemampuan awal mahasiswa menulis cerpen, selanjutnya penulis merancang skenario pembelajaran dengan menerapkan pendekatan proses dalam pembelajaran menulis cerpen. Pelaksanaan pembelajaran dirancang mengikuti langkah-langkah (a) prapenulisan, (b) membuat draf, (c) merevisi, (d) menyunting, dan (e) mempublikasikan. Kegiatan pembelajaran disusun untuk 4 (empat) kali pertemuan, masing-masing pertemuan dilaksanakan dengan alokasi waktu 100 menit.

Tahap Pelaksanaan. Tahap pelaksanaan dilaksanakan dalam 5 (lima) kali pertemuan. Pelaksanaan pembelajaran mengikuti jadwal perkuliahan yang telah tersusun. Pertemuan pertama dilaksanakan Selasa 20 September 2016, pertemuan kedua Selasa 27 September 2016, pertemuan ketiga Selasa 4 Oktober 2016, pertemuan keempat Selasa 11 Oktober 2016, dan pertemuan kelima Selasa 18 Oktober 2016. Adapun rincian kegiatan setiap pertemuan dijabarkan sebagai berikut.

Pertemuan pertama dilaksanakan Selasa 20 September 2016 pukul 07.00-09.10 WIB. Dosen menjelaskan mengenai cerpen dan unsurunsur pembangunnya. Pembelajaran menulis cerpen dilaksanakan mengacu pada pendekatan proses. Pada pertemuan pertama ini setiap mahasiswa diminta menuliskan kegemarannya di papan tulis secara bergantian. Setelah semua selesai menuliskan kegemarannya, mahasiswa 
diminta mengelompokkan kegemaran yang sama. Selanjutnya mahasiswa diminta berkelompok sesuai dengan kegemarannya. Jumlah anggota tiap kelompok bervariasi tergantung dari jumlah kegemaran yang sama. Mahasiswa diminta mendiskusikan kerangka karangan berdasarkan kegemaran di kelompok masing-masing. Pertemuan pertama berakhir dengan hasil setiap mahasiswa telah memiliki kerangka karangan masing-masing. Pekerjaan mahasiswa dikumpulkan untuk sementara, dengan pertimbangan tidak ada yang mengerjakan lanjutannya di rumah. Tugas akan dilanjutkan pada pertemuan berikutnya.

Pertemuan kedua dilaksanakan Selasa 27 September 2016 pukul 07.00-09.10 WIB. Pada pertemuan kedua ini, pembelajaran dilakukan secara individu. Mahasiswa ditugaskan mengembangkan kerangka karangan yang telah disusun secara berkelompok. Beberapa mahasiswa terlihat bingung memimikirkan apa yang akan ditulis. Dosen membimbing mahasiswa dengan cara menanyakan permasalahan yang dihadapi saat menulis cerpen. Sampai pembelajaran berakhir, semua mahasiswa belum menyelesaikan cerpen sampai selesai. Pembelajaran dilanjukan pertemuan berikutnya. Kembali dosen mengumpulkan pekerjaan mahasiswa dengan tujuan yang sama, agar tidak ada yang melanjutkan menulis cerpen di rumah.

Pertemuan ketiga dilaksanakan Selasa 4 Oktober 2016 pukul 07.00-09.10 WIB. Pembelajaran yang dilaksanakan masih melanjutkan kegiatan yang belum selesai di pertemuan kedua. Mahasiswa kembali melanjutkan cerpen yang belum selesai. Pada pertemuan ketiga ini, mahasiswa begitu seksama mengerjakan cerpennya masing-masing. Terlihat sesekali mahasiswa berbicara dengan teman di sebelahnya. Dosen memperbolehkan ini, selama yang dicicarakan masih berfokus pada pekerjaan yang diberikan. Di akhir pembelajaran semua mahasiswa telah menyelesaikan cerpennya sampai pada akhir cerita menurut persepsi masing-masing. Kembali dosen mengumpulkan pekerjaan mahasiswa dengan tujuan yang sama.

Pertemuan keempat dilaksanakan Selasa 11 Oktober 2016 pukul 07.00-09.10 WIB. Fokus pembelajaran hari ini pada kegiatan merevisi dan mengedit cerpen yang telah dibuat. Mahasiswa melakukan proses merevisi cerpen dengan cara membaca ulang cerpen yang diibuat kemudian mengganti atau menambah bagian yang belum sempurna. Setelah proses selesai dilaksanakan, mahasiswa mengedit cerpen dari sisi ejaan dan tanda baca berpedoman pada EYD (Ejaan Yang Disempurnakan). Proses revisi dan mengedit selesai, mahasiswa diminta menukarkan cerpennya masing-masing dengan teman yang berdekatan. Dosen meminta mahasiswa saling membaca cerpen temannya dan menugaskan menentukan judul yang tepat dari cepren yang dibaca. Setelah semua selesai menentukan judul cerpen, dosen meminta mahasiswa membacakan judul yang dibuat dan mencocokkan dengan dengan pendapat mahasiswa pembat cerpen untuk mencocokkan ide yang diberikan. Pembelajaran selesai. Mahasiswa puas dengan hasil cerpen yang dibuat. Kembali dosen mengumpulkan pekerjaan mahasiswa dengan tujuan yang sama. Pertemuan dilanjutkan minggu depan dengan agenda pembelajaran publikasi cerpen yang telah dibuat.

Pertemuan kelima dilaksanakan Selasa 18 Oktober 2016 pukul 07.00-09.10 WIB. Fokus pembelajaran pada kegiatan publikasi. Mahasiswa secara acak diminta membacakan hasil cerpen yang telah dibuatnya, mahasiswa yang lain memberikan komentar atau respon dari isi cerpen. Mahasiswa terlihat puas dengan kegiatan pembelajaran menulis cerpen yang telah disampaikan dosen. Hal ini terlihat dari respon positif yang diberikan setelah pembelajaran berakhir.

Tahap Analisis Data. Analisis data keterampilan menulis cerpen mengacu pada penilaian hasil karangan (Burhan Nurgiantoro, 
2009:306) dengan pengembangan secukupnya. Kisi-kisi penilaian dipilih karena sudah memenuhi kelengkapan baik dari segi penilaian isi maupun mekanik. Bobot skor pada tiap aspek didasarkan pada tingkat pentingnya masing-masing aspek dalam karangan.

Tabel 2. Keterampilan Menulis Cerpen Sebelum Menggunakan Pendekatan Proses

\begin{tabular}{ccc}
\hline No. Subjek & Jumlah Skor & Nilai \\
\hline S01 & 28 & 56 \\
\hline S02 & 28 & 56 \\
\hline S03 & 28 & 56 \\
\hline S04 & 29 & 58 \\
\hline S05 & 40 & 80 \\
\hline S06 & 28 & 56 \\
\hline S07 & 30 & 60 \\
\hline S08 & 30 & 60 \\
\hline S09 & 31 & 62 \\
\hline S10 & 31 & 62 \\
\hline S11 & 28 & 56 \\
\hline S12 & 33 & 66 \\
\hline S13 & 33 & 66 \\
\hline S14 & 29 & 58 \\
\hline S15 & 29 & 58 \\
\hline S16 & 28 & 56 \\
\hline S17 & 28 & 56 \\
\hline S18 & 33 & 66 \\
\hline S19 & 29 & 58 \\
\hline S20 & 29 & 58 \\
\hline S21 & 36 & 72 \\
\hline S22 & 30 & 60 \\
\hline S23 & 32 & 64 \\
\hline S24 & 28 & 56 \\
\hline S25 & 35 & 70 \\
\hline S26 & 28 & 56 \\
\hline S27 & 35 & 70 \\
\hline Jumlah & $\mathbf{8 2 6}$ & $\mathbf{1 6 5 2}$ \\
\hline Rata-rata & $\mathbf{3 0 , 5 9}$ & $\mathbf{6 1 , 1 9}$ \\
\hline & & \\
\hline & & \\
\hline & & \\
\hline
\end{tabular}

Tabel 3. Keterampilan Menulis Cerpen Setelah Menggunakan Pendekatan Proses

\begin{tabular}{|c|c|c|}
\hline $\begin{array}{c}\text { No. } \\
\text { Subjek }\end{array}$ & $\begin{array}{c}\text { Jumlah } \\
\text { Skor }\end{array}$ & Nilai \\
\hline S01 & 44 & 88 \\
\hline S02 & 44 & 88 \\
\hline S03 & 40 & 80 \\
\hline S04 & 42 & 84 \\
\hline S05 & 47 & 94 \\
\hline S06 & 44 & 88 \\
\hline S07 & 44 & 88 \\
\hline S08 & 43 & 86 \\
\hline S09 & 41 & 82 \\
\hline S10 & 41 & 82 \\
\hline S11 & 42 & 84 \\
\hline S12 & 41 & 82 \\
\hline S13 & 42 & 84 \\
\hline S14 & 41 & 82 \\
\hline S15 & 42 & 84 \\
\hline S16 & 38 & 76 \\
\hline S17 & 40 & 80 \\
\hline S18 & 42 & 84 \\
\hline S19 & 41 & 82 \\
\hline S20 & 44 & 88 \\
\hline S21 & 39 & 78 \\
\hline S22 & 43 & 86 \\
\hline $\mathbf{S 2 3}$ & 41 & 82 \\
\hline S24 & 40 & 80 \\
\hline S25 & 43 & 86 \\
\hline S26 & 42 & 84 \\
\hline S27 & 39 & 78 \\
\hline Jumlah & 1130 & 2260 \\
\hline Rata-rata & 41,85 & 83,70 \\
\hline
\end{tabular}

Berdasarkan tabel 2 dan tabel 3 di atas, ratarata keterampilan menulis cerpen mahasiswa sebelum menggunakan pendekatan proses adalah 61,19 dengan kriteria cukup (55-70) dan setelah menggunakan pendekatan proses menjadi 83,70 dengan kriteria baik (71-85).

\section{Pembahasan Penelitian}

Pelaksanaan pembelajaran menulis cerpen lewat pendekatan proses yang telah dilaksanakan dalam 5 (lima) kali pertemuan memfokuskan 
pada bentuk kegiatan menulis cerpen secara terstruktur. Dosen harus memperhatikan seluruh mahasiswa dalam praktik menulis cerpen ini agar diperoleh hasil yang optimal. Pembelajaran ini dimulai dari tahap penggalian ide sampai pada tahap publikasi. Aktivitas mahasiswa dalam pembelajaranmengalami peningkatan sehingga pembelajaran lebih efektif dan menyenangkan. Pembelajaran menulis cerpen dengan mengikiti tahapan pendekatan proses mampu menciptakan proses pembelajaran yang menyenangkan dan menantang, hal ini tercermin dari antusias mahasiswa dalam mengerjakan tugas menulis cerpen. Mahasiswa merasa tidak bosan dengan aktivitas pembelajaran yang telah dilakukan.

Pembelajaran menulis cerpen yang sering dianggap tidak menarik atau sulit karena harus merangkai sebuah cerita dapat teratasi. Bimbingan yang diberikan mulai dari tahap prapenulisan sampai mempublikasikan dapat membantu mahasiswa mengembangkan sebuah cerita dan imajinasinya. Pembelajaran menulis dengan mengikuti tahapan pendekatan proses dapat membantu dosen memberikan variasi dan rangsangan dalam tugas menulis cerpen yang diberikan.

Pembelajaran menulis yang menekankan pada proses memiliki kebaikan apabila dibandingkan dengan model pembelajaran menulis konvensional, yaitu lebih banyak diorientasikan pada produk. Kebaikan-kebaikan itu antara lain (a) mahasiswa dapat menyatakan gagasannya serta menyadari gagasan yang disampaikannya itu, (b) mahasiswa dapat mengetahui bahwa ia dapat belajar dari gagasan teman atau yang lainnya, (c) mahasiswa dapat belajar bahwa gagasan yang akan ditulisnya dapat diperoleh dalam beberapa jalan/cara, (d) mahasiswa dapat mulai menulis dengan tidak benar atau tidak sempurna, (e) mahasiswa dapat belajar menerima, mengevaluasi dan menerapkan gagasan yang diperolehnya dari teman lain, (f) mahasiswa dapat memonitor dan memperbaiki tulisannya sendiri, (g) mahasiswa dapat merasa bangga akan pekerjaannya dan kesenangan itu dikomunikasikan dalam kegiatan menulis, membaca, menyimak, dan berbicara, (h) mahasiswa dapat mengembangkan kemandirian dalam berpikir, dan (i) mahasiswa dapat merealisasikan apa yang telah diinginkan melalui pemusatan gagasan yang telah dipilihnya sendiri.

Keterampilan menulis cerpen mahasiswa mengalami perubahan yang signifikan dibanding dari tes awal meulis cerpen yang diberikan. Hal ini dapat dilihat dari hasil perbandingan sebelum dan sesudah menggunakan pendekatan proses. Keterampilan menulis cerpen mahasiswa sebelum menggunakan pendekatan proses 61,19 dengan kriteria cukup (55-70) dan setelah menggunakan pendekatan proses 83,70 dengan kriteria baik (71-85). Untuk lebih jelasnya dapat dilihat pada tabel berikut ini.

\section{Menulis Cerpen}

\begin{tabular}{|c|c|c|}
\hline $\begin{array}{c}\text { No. } \\
\text { Subjek }\end{array}$ & $\begin{array}{l}\text { Nilai } \\
\text { Awal }\end{array}$ & Nilai Akhir \\
\hline S01 & 56 & 88 \\
\hline S02 & 56 & 88 \\
\hline S03 & 56 & 80 \\
\hline S04 & 58 & 84 \\
\hline S05 & 80 & 94 \\
\hline S06 & 56 & 88 \\
\hline S07 & 60 & 88 \\
\hline S08 & 60 & 86 \\
\hline S09 & 62 & 82 \\
\hline S10 & 62 & 82 \\
\hline S11 & 56 & 84 \\
\hline S12 & 66 & 82 \\
\hline S13 & 66 & 84 \\
\hline S14 & 58 & 82 \\
\hline S15 & 58 & 84 \\
\hline S16 & 56 & 76 \\
\hline S17 & 56 & 80 \\
\hline S18 & 66 & 84 \\
\hline S19 & 58 & 82 \\
\hline $\mathbf{S 2 0}$ & 58 & 88 \\
\hline $\mathbf{S 2 1}$ & 72 & 78 \\
\hline $\mathbf{S 2 2}$ & 60 & 86 \\
\hline $\mathbf{S 2 3}$ & 64 & 82 \\
\hline S24 & 56 & 80 \\
\hline $\mathbf{S 2 5}$ & 70 & 86 \\
\hline S26 & 56 & 84 \\
\hline $\mathbf{S 2 7}$ & 70 & 78 \\
\hline Jumlah & 1652 & 2260 \\
\hline Rata-rata & 61,19 & 83,70 \\
\hline
\end{tabular}


Berdasarkan tabel di atas dapat disimpulkan bahwa pembelajaran menulis menggunakan pendekatan proses dapat meningkatkan keterampilan menulis cerpen mahasiswa dan memberikan dampak positif terhadap kegiatan pembelajaran di kelas.

\section{SIMPULAN DAN SARAN \\ Simpulan}

Berdasarkan hasil dan pembahasan dalam penelitian ini dapat disimpulkan bahwa pendekatan proses dapat meningkatkan keterampilan menulis cerpen mahasiswa. Peningkatan ini dapat dilihat dari proses maupun produk. Pembelajaran menulis dengan mengikuti tahapan pendekatan proses dapat membantu dosen memberikan variasi dan rangsangan dalam tugas menulis cerpen yang diberikan. Secara proses peningkatan dapat dilihat dari proses pembelajaran menulis kreatif dengan pendekatan proses dalam kegiatan siswa dan situasi kelas dalam pembelajaran menulis kreatif puisi. Keterampilan menulis cerpen mahasiswa mengalami perubahan yang siignifikan. Hal ini dapat dilihat dari hasil perbandingan sebelum dan sesudah menggunakan pendekatan proses. Keterampilan menulis cerpen mahasiswa sebelum menggunakan pendekatan proses 61,19 dengan kriteria cukup (55-70) dan setelah menggunakan pendekatan proses 83,70 dengan kriteria baik (71-85).

\section{Saran}

Pembelajaran menulis yang menekankan pada proses memiliki kebaikan apabila dibandingkan dengan model pembelajaran menulis konvensional, yaitu lebih banyak diorientasikan pada produk. Keterampilan menulis cerpen mahasiswa mengalami perubahan yang signifikan dibanding dari tes awal menulis cerpen yang diberikan. Pembelajaran menulis menggunakan pendekatan proses dapat meningkatkan keterampilan menulis cerpen mahasiswa dan memberikan dampak positif terhadap kegiatan pembelajaran di kelas. Dengan demikian, pendekatan proses dapat dijadikan satu alternatif dalam pembelajaran keterampilan menulis dan tidak menutup kemungkinan untuk digunakan dalam pembelajaran keterampilan menyimak, berbicara, dan membaca.

\section{DAFTAR RUJUKAN}

Aminuddin. 1990. Pengembangan Penelitian Kualitatif dalam Bidang Bahasa dan Sastra. Malang: YA3.

Caraka, C.L. 2002. Teknik Mengarang. Yogyakarta: Kanisius.

Miles, Matthew B. dan Michael A. Hubberman. 1992. Analisis Data Kualitatif. Terjemahan oleh Tjetjep Rohendi Rohidi. Jakarta: UI Press.

Natia, I.K. 1994. Bimbingan Mengarang. Surabaya: Arkola.

Nurchasanah dan Widodo. 1993. Keterampilan Menulis dan Pengajarannya. Malang: Fakultas Sastra Universitas Negeri Malang.

Nurgiyantoro, Burhan. 2009. Penilaian dalam Pengajaran Bahasa dan Sastra. Yogyakarta: BFFE-Yogyakarta.

Sayuti, Suminto A. 2009. Berkenalan dengan Prosa Fiksi. Yogyakarta: Gama Media.

Semi, M. Atar. 2003. Menulis Efektif. Padang: Angkasa Raya.

Sumardjo, Jacob. 2007. Catatan Kecil tentang Menulis Cerpen. Yogyakarta: Pustaka Pelajar.

Tarigan, Henry Guntur. 1986. Menulis sebagai Suatu Keterampilan Berbahasa. Bandung: Angkasa.

Tompkins, Gail E.and Kenneth Hoskisson. 1995. Language Arts: Content and Teaching Strategies. Englewood Cliffis, New Jersy: Prentice-Hall, Inc. 